\author{
SANDRA SOLER CAMPO \\ Universidad de Barcelona, Barcelona, Spain \\ ORCID: 0000-0002-5560-1415, sandra.soler@ub.edu
}

\title{
José Soler Casabón and his Ballet L'Homme sans yeux, sans nez et sans oreilles and his Poetry Fonds Perdu
}

José Soler Casabón was a Spanish composer and poet who was born on 31 August 1884 in Mequinenza (Zaragoza, Spain), and died on 3 March 1964 in Paris. Although little is known about his life and work, some of his masterpieces have been preserved, as the result of which it can be affirmed that he was excellent composer of his time. In this article we will focus on what is perhaps his greatest work, his ballet titled L'Homme sans yeux, sans nez et sans Oreilles (Ho.S.Y.N.O.) which was created in 1917 and, unfortunately, has not yet premiered been. In addition to being a musician, he was also a poet. His musical background can be seen in his writings. His poetic work Fonds Perdu, which has been preserved, provides a clear example of this.

Keywords: Apollinaire, ballet, composer José Soler Casabón, Paris, poetry.

For citation / Для цчитирования: Soler Campo Sandra. José Soler Casabón and his Ballet L'Homme sans yeux, sans nez et sans oreilles and his Poetry Fonds Perdu // Проблемы музыкальной науки / Music Scholarship. 2021. № 2. С. 148-155.

DOI: $10.33779 / 2587-6341.2021 .2 .148-155$.

(C) Sandra Soler Campo, 2021

(C) Publisher: Scholarly-Methodical Center "Innovation Art Studies," 2021

\section{САНДРА СОЛЕР КАМПО}

Барселонский университет, г. Барселона, Испания

ORCID: 0000-0002-5560-1415,sandra.soler@ub.edu

\section{Хосе Солер Касабон, его балет «L'Homme sans yeux, sans nez et sans oreilles» («Человек без глаз, без носа и без ушей») и поэзия «Fonds Perdu» («Потерянные капиталы»)}

Хосе Солер Касабон - испанский композитор и поэт, родился 31 августа 1884 года в Мекиненце (Сарагоса, Испания) и умер 3 марта 1964 года в Париже. Хотя о его жизни и творчестве известно мало, некоторые из его шедевров сохранились, благодаря чему можно утверждать, что он был замечательным композитором своего времени. Эта статья сосредоточена на том, что, возможно, является его величайшим произведением, - его балете «L'Homme sans yeux, sans nez et sans Oreilles» («Ho.S.Y.N.O.») («Человек без глаз, без носа и без ушей»), созданном в 1917 году и, к сожалению, до сих пор не дождавшемся премьеры. Помимо того, что Хосе Солер Касабон был музыкантом, он также был поэтом. Его музыкальные взгляды можно наблюдать в литературных произведениях. Сохранившееся 
поэтическое произведение «Fonds Perdu» («Потерянные капиталы») является ярким примером этого.

Ключевые слова: Аполлинер, балет, композитор Хосе Солер Касабон, Париж, поэзия.

(C) Сандра Солер Кампо, 2021

(C) Издатель: АНО ДПО НМЦ «Инновационное искусствознание», 2021

\section{INTRODUCTION}

During the first decades of the 20th century many economic, political and cultural changes took place which transformed society deeply. The domain of art was not an exception in the context of these changes. As a result of this a great number of avant-garde artistic trends, aesthetic currents and thoughts developed successively at a speed never witnessed before in history. Paris was one of the European cities where this cultural and artistic fervor developed most intensely. It soon became one of Europe's most prominent capitals, so that a large number of musicians, poets and writers moved to the French capital in order to feel such influences and to enrich them artistically. This was the case of the Spanish composer José Soler Casabón, who decided to settle in Paris and develop his career as a musician and poet there.

The composer immediately surrounded himself with famous writers, musicians, painters and various prominent personalities from the French artistic scene. He established a very close relationship with the great poet Guillaume Apollinaire and collaborated with him on his great work, the ballet titled L'Homme sans yeux, sans nez et sans Oreilles (Ho.S.Y.N.O.).

Guillaume Apollinaire envisaged a ballet based on his poem Le Musicien de Saint Merry, and in 1917 José Soler Casabón took over the project, having modified it to a small degree, and it was renamed Ho.S.Y.N.O. The poem's plot Le Musicien de Saint-Merry is about a flautist who has no face, who travels through an ancient Parisian neighborhood. In June of the same year, Soler Casabón composed a version of the ballet for two pianos and completed the final version of it five months later [2, p. 32].

Soler Casabón, according to information provided by an address book of Apollinaire's and a business card given to Picasso ${ }^{1}$, reported the scene: "I want you to compose the music," Apollinaire said, "because it must be full of passion. I told him before that he should entrust the writing of the music to another composer, more capable than I, and especially one more mature - Erik Satie for example, who had just produced the marvel of Parade and whom I also greatly revere" [6, p. 5]. Overall, the atmosphere that Soler Casabón recreates for this ballet is very tragic. For this reason, had the ballet been premiered, it would probably not have left the public indifferent.

On November 9, 1918, Apollinaire died. Consequently Soler Casabón was greatly discouraged and decided to return temporarily to Barcelona where he wrote in French "I'll file this music away" [6, p. 11]. As a consequence of the death of his great friend Apollinaire, (which left the composer devastated), the war and all of its consequences (such as, for instance, the closure of theatres and the cancellation of a large number of cultural events) the ballet was never performed. 
A few years later, in 1934, when Soler Casabón was once again in Paris, he orchestrated the Prelude and the first tableau of (Ho.S.Y.N.O.). The manuscript of the musical composition consisted of 22 pages with 32 musical staves each ${ }^{2}$.

During the following years, Soler Casabón radicalized his music (possibly as a consequence of the various social changes that took place during the first decades of the century) and did not cease to try to have his ballet performed, but, due to a variety of causes, it remained impossible to premiere it. He lived up to his last days in extreme poverty and died on 9 March, 1964. Until the very end, after several attempts to make his dream come true, he was never able to stage his ballet. After his demise, up to the present time in the 21 st century it has not been possible to carry out Soler Casabón's dream.

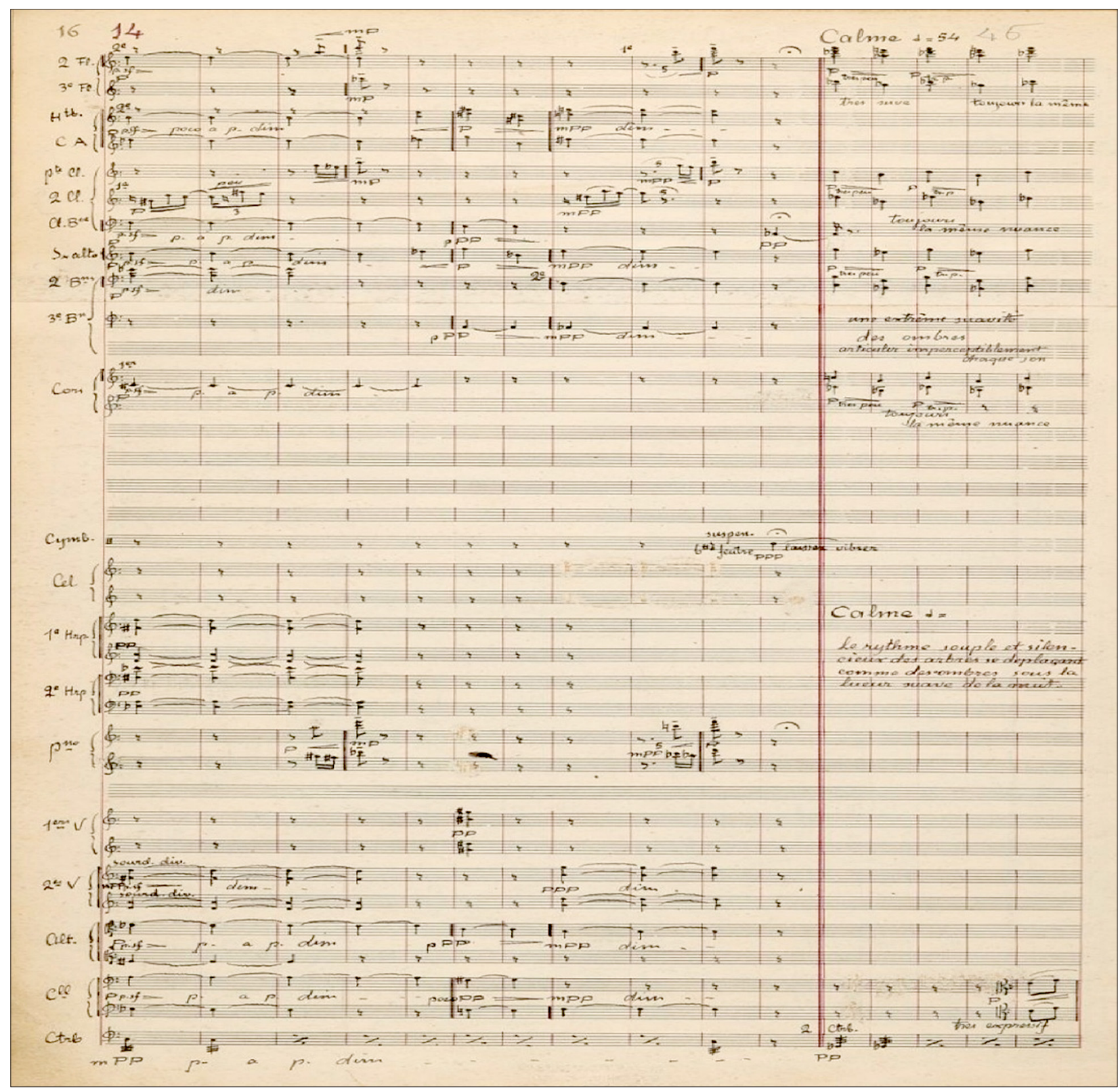

Image 1.Fragment of Ho.S.Y.N.O.

Source: Bibliothèque Nationale de Paris: Bibliothèque Nationale de Paris 


\section{SOME CONSIDERATIONS CONCERNING L'HOMME SANS YEUX, SANS NEZ ET SANS OREILLES}

L'Homme sans yeux, sans nez et sans oreilles is a ballet in two acts and eleven scenes, Prélude, Interlude and Epilogue. Some of the scenes have peculiar titles, such as, for instance, Danse de la lumière et les mouches ${ }^{3}$ ( ${ }^{\text {re }}$ Tableau, Ire Scène), Départs de chemins de fer (2me Tableau, $2^{e}$ Scène) or La douceur des fleuves européens ( $2^{e}$ Tableau, $5^{e}$ Scène), whereas others are simply numbered, but unttled.

The full score contains many stage directions, such as those we see at the beginning of the second act:

A small square, a small fountain on the left, where the monuments line up. In the small square, several streets are visible. A man without eyes, without a nose and without ears advances slowly from the right playing a flute. He soon stops playing, and when he is close to the wings of the stage, little by little various women of all descriptions gather around him: blondes, brunettes, a naked woman, a headless woman, etc. When they are gathered, the man walks slowly to the fountain followed by the women. At the fountain, the man stops playing and drinks. The bell rings; the women hurry to see him, to hold him. Straight away, the man resumes his playing and regresses the way he came followed by the women. More women come from different parts of the stage, with outstretched hands, and deranged eyes, the music dies down. ${ }^{4}$

Even if the script were no longer available, the wealth of knowledge accrued around the figure of Apollinaire, his work and his aesthetics could be sufficient to assume a significant amount of surrealism, often coming very close to and even merging with symbolism, as can be seen in some other works by this composer. Soler Casabón can - and, in our opinion, must be understood from this same perspective and is therefore framed in a "musical and philosophical discourse" that "claims to define an authentic new musical philosophy" and that "reveals its best illustration $<\ldots$... in the music by those composers who, like Debussy, were in search of an alternative to the stated expressivity based on a path full of pride and predetermination" [3, p. 38].

The stated expressivity mentioned in this quotation is that which veers towards dramatic emotionalism that can be heard in the German post-romanticism of Mahler and Richard Strauss, and that provides an important counterpoint to those contemporary musicians, whose works were usually lyrical, subtle, evocative and surreal.

Thus, the "old-time" dichotomy between impressionism and symbolism in the music of these composers is today more than ever of dubious value if its aim is not to reveal what lies behind its maximal aesthetics. At the same time, it is hardly helpful to define them as an opposition to both the classical and the romantic conceptions of development and continuity, since their vision on musical structuring has had no parallel, so far. Their orchestration becomes transforms into "a musical palette that is muted and even colourless, with a great prevalence of delightful shades of grey" [5, p. 32]. Once again, these features may be appreciated in the music of a number of other composers, such as, for instance, Erik Satie's Parade, a ballet we already mentioned and that we will use as a point of contrast to Ho.S.Y.N.O. because of the extensive connections existing between them.

Both ballets demonstrate a similar approach to orchestration and to their treatment of musical development. With 
regard to the former, some aspects may be mentioned: the use of rare percussion instruments - even the incorporation of unusual sounds we would hardly consider as musical, such as typewriters etc. which provide a coloristic and textural element that transforms the concept of the orchestra as a whole. As to the latter, we find that the use of abrupt interruptions, as a modus operandi brought in to juxtapose different musical images, is an element shared by both ballets, as also by others, such as Igor Stravinsky's Le Sacre $d u$ Printemps - perhaps the greatest example of this technique. To strike a comparison with the other arts, Picasso's cubism in his paintings and Duchamp's ready-mades may be considered stylistically aligned with this technique.

In reference to the harmonic textures common to the composers of this era, we find, for instance, that the concepts of progression and voice-leading give way to observation and appreciation of texture, developmental stasis and sound blocks. This generation of composers is especially extraordinary, since it has brought into music one of the earliest, examples of tonal suspension, that is, the suspension of the musical system that has prevailed in Western music for centuries, and that here appears to be illusory and virtually unreal.

All of these traits can be observed in abundance in Soler Casabón's musical score. Of particular interest are the innovative concepts of time, meter and their structuring; the sinuous, undramatic orchestration, which at times is reminiscent of chamber music; the use of broad sound blocks of extreme tonal ambiguity ${ }^{5}$, which provides a symbolic prism through which it becomes easier to view his interpretation of script and stage narrative.

We see the need for a musicological article such as this as a first step along the path, on the one hand, towards publishing Soler Casabón's major musical composition, and, on the other hand, as a means by which to reveal the aesthetic and technical qualities present in his work. This article may be supplemented throughout by reference to the full score, which provided the main material used for the development of this article and which can be found on the website of the Bibliothèque Nationale de France. In addition to presenting this article to the public, we would like to invite all those to whom it might concern to give a premiere performance and to record this great composition, especially considering its ill-fated history of cancellations up until the present day and the fact that its luck does not appear to have changed even after its hundredth anniversary.

As will be shown later, so many elements are involved in establishing the high value of this work, whether in terms of composition or orchestration. Particularly in the latter, the use of impressionistic instrumental and orchestral resources must be emphasized - most notably, the piano and the harps as textural and coloristic elements, the saxophone as a timbral extension of the woodwind group, as well as the frequent intricate divisi of the strings. With the exception of the double basses, all the other instrumental groups are often divided into two or four parts, and this arrangement occurs more frequently than the writing for these groups in unison ${ }^{6}$. The historical and the geographical contexts offer examples of the composers with whom the composer can be in some ways compared, especially from an aesthetic angle. Satie, Debussy, Ravel, Albéniz, Falla and Stravinsky can all be associated in various ways with Soler Casabón.

As has already been mentioned, the analysis of this musical composition is based, on the original manuscript of the 
orchestral score, which provides an immense opportunity to take notice of such details that often go unnoticed, or even disappear after the first edition.

Here the precision of the dynamics can be discussed. Instead of using the usual gradient between pianissimo and fortissimo, Soler Casabón, instead, uses terms like molto, poco and quasi in addition to the usual ones, such as quasi sforzando, molto mezzo piano or poco diminuendo, disclosing a new poetical dimension to dynamic interpretation. Other markings such as dim. proportionnellement peu à peu $^{7}$, en dehors (oboe, page 20$)^{8}$, claire mais suave $e^{9}$ and many others, truly testify to the formidable precision with which the composer conceives his musical ideas.

This also applies to the use of symbols and other special indications, such as articulation signs: "Sometimes I use the symbol to indicate less marked attack, compared with the usual accent mark (>)"; or commas and fermatas: "We know that a comma between two notes provides a slight interruption to the sound, but not the meter. When placed above a bar line or a rhythmic line - thicker bar lines - it interrupts both the sound and the meter. When the comma appears after a bar line crowned with a fermata, the interruption is longer. When there is a fermata by itself, it is even longer." 10

These and other examples can be found throughout the score, which suffices to demonstrate the breathtaking precision and conciseness with which José Soler Casabón treats his musical ideas, as well as the profound attention to detail in his orchestral scoring.

\section{MUSIC AND POETRY}

José Soler Casabón was a musician and poet who lived and developed between Mequinenza, Barcelona and, above all,
Paris during a large portion of the 20th century. While his facet as a composer is very little known, he is even less known as a poet. We do not have the information at present how many works he wrote, since he lived in extreme poverty and when he died many of his belongings disappeared, including, in all likelihood, the manuscripts of his poems and musical scores. However, it is worth mentioning a poetic work entitled Fonds Perdu (Lost Funds). This work consists of 43 poems written in French, chronologically relating to two periods of his life. The first period includes poems written from 1912 to 1920 and the second period from 1932 to 1939 . Fonds perdu was dedicated to Camille Soula, an Occitan doctor and physiologist. The work was printed on 23 December 1939, and a numbered edition was published, limited to 34 copies, 30 of them on straw paper and 4 on cloth paper.

In May 1940, Soler Casabón sent several copies of his book of poetry to his close friends. For example, No. 2 was dedicated to his close friend, poet Pierre Reverdy, while No. 25 was sent on 12 May to Pablo Picasso. Among the different poems, one of them was dedicated to music, and he gave it the title of Souhait (Desire).

\section{Souhait}

Je suis comme un oiseau

Qui aurait perdu son chant Je suis un musicien

Perdu dans le lointain

De sons insoupçonnés. Je veux que mes paroles Deviennent des paraboles D'une langue n'existant Et veux que de mes pas A la démarche chimérique

Un chant énigmatique S'élève a la gréve. 


\section{CONCLUSION}

José Soler Casabón was undoubtedly an outstanding personality from the 20th century who, due to various circumstances of fate, including World War I, the Spanish Civil War, and the death of his close friend Guillaume Apollinaire, among others, did not see his artistic work recognized during his lifetime.

Although he mastered the most current compositional techniques of his time, as can be seen in the analysis of his compositions carried out by different Spanish and French musicologists, he managed to achieve a very personal style of his own. Thus, for example, he explored of a system that he called système commatic, which was very similar to the compositional technique used by composers who were is contemporaries in Germany, Austria and France, such as, for example, Schoenberg and Debussy ${ }^{11}$. It can therefore be argued that Soler Casabón demonstrated interest not only in the compositional techniques that were being developed in France, but also in the German and Austrian musical innovations that were being developed at the same time.

Among his achievements as a poet, since we do not know how many works, both musical and literary, were written by him, many of which were lost, the work that at least was published, Fonds Perdu, must be highlighted.

Mequinenza, his native town, pays tribute to him and his memory regularly and encourages musicologists and historians from all over the world to continue researching his legacy with the aim of highlighting the life and work of a composer and poet who is largely unknown both for the general public and for the community of scholars.

\section{Oro NOTES Oro}

1 Letter written by José Soler Casabón to Picasso (1917). Picasso Museum. Paris.

2 Pablo Gargallo, a great sculptor, friend and compatriot of Soler Casabón, died in 1934 at a time of great artistic fulfillment for him. That same year, very likely, in memory of his friend, Soler Casabón resurfaced in his artistic endeavors andorchestrated the prelude and first act of H.O.S.Y.N.O, in a 22-page manuscript.

3 This title, as all the others, textes and interprétations musicales, shown in this article, have been extracted from the original manuscript.

4 Soler Casabón, original manuscript of Ho.S.Y.N.O.. p. 33.

5 As one may see in the music of those composers, Soler Casabón achieves a keen perception of the chord (i.e., group of three or more pitches performed simultaneously) completely withdrawn from any tonality. Thus, in his music it becomes usual to find six-pitch chords (encompassing half of the twelve standard pitches available in the tonal system).

6 Similar to the way Debussy does in his orchestral pieces, such as La Mer (1905).

7 Soler Casabón, original manuscript, Flutes part, p. 17.

8 Idem, Oboes part, p. 20.

9 Idem, Horn, p. 25.

${ }^{10}$ Idem, p. 32.

${ }^{11}$ Soler Casabón's harsh experience of the war impelled him to make a radical break with the aesthetic movements of the early 20th century. The système commatic used by the composer provided a division of the musical scale into quarter-tones and commas, instead of tones and semitones, 
following his own method of signs. Soler Casabón structured and used his musical language in such a way that the division of the scales would be arranged not into tones and semitones, but into quarter tones and commas.

\section{Or REFERENCES}

1. Apollinaire G. Calligrammes. Poèmes de la Paix et de la Guerre 1913-1916. Paris: Mercure de France, 1918. 205 p.

2. Estruga J. José Soler Casabón y Apollinaire. Un ballet de Apollinaire, con decorados de Picasso y música de José Soler Casabón, que no llegó a representarse en la escena nacional francesa. Rolde: Revista de cultura aragonesa. 2007, 123, pp. 28-37.

3. Fubini E. El siglo XX: Entre Música y Filosofía. València: Publicaciones de la Universitat de València (PUV), 2014. $182 \mathrm{p}$.

4. Lisciani-Petrini E. Tierra en Blanco. Música y Pensamiento a Inicios del Siglo XX. Madrid: Akal Ediciones, 1999. 112 p.

5. Top D. A la Recherche du Ballet Perdu. Le musicien de Saint Merry. Que Vlo-Ve? 2004. No. 25, pp. 1-35.

About the author:

Sandra Soler Campo, Ph.D. (Music Pedagogy, University of Rovira i Virgili), Professor and Researcher at the Department of Music, University of Barcelona (08007, Barcelona, Spain), ORCID: 0000-0002-5560-1415, sandra.soler@ub.edu

\section{Об авторе:}

Сандра Солер Кампо, Ph.D. (Музыкальная педагогика, Университет Ровира и Вирджили), профессор, научный сотрудник музыкального факультета, Барселонский университет (08007, г. Барселона, Испания), ORCID: 0000-0002-5560-1415, sandra.soler@ub.edu

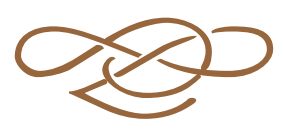

